\title{
Pengaruh Besar Butir dan Temperatur Pemanasan Pasir Cetak Terhadap Sifat Mekanis Cetakan
}

\author{
Braam Delfian Prihadianto $^{1 *}$, Radhian Krisnaputra ${ }^{2}$, Suryo Darmo $^{3}$, Aldi Prabowo ${ }^{4}$ \\ 1,2,3,4 Departemen Teknik Mesin, Sekolah Vokasi, Universitas Gadjah Mada \\ 1,2,3,4 Jalan Yacaranda, Sekip Unit IV Yogyakarta \\ E-mail: braam.delfian@ugm.ac.id ${ }^{1}$, radhian_kp@ugm.ac.id ${ }^{2}$, sur_yadar_ma@yahoo.com.sg ${ }^{3}$, \\ aldiprabowoo@gmail.com ${ }^{4}$
}

\section{Info Naskah:}

Naskah masuk: 13 November 2020

Direvisi: 15 Maret 2021

Diterima:17 Maret 2021

\begin{abstract}
Abstrak
Pengecoran merupakan proses manufaktur yang menggunakan logam cair dan cetakan untuk memperoleh produk yang mendekati geometri akhirnya. Kualitas produk pengecoran dipengaruhi oleh beberapa hal dan salah satu yang menjadi bagian penting adalah cetakan. Pasir yang sering digunakan pada pembuatan cetakan adalah resin coated sand, dimana pasir ini akan terikat satu dengan lainnya jika dilakukan pemanasan. Fokus penelitian ini adalah untuk mengetahui pengaruh besar butir dan temperatur pemanasan resin coated sand terhadap sifat mekanis cetakan yang meliputi kekuatan tekan, kekuatan geser, dan kekuatan tarik. Penelitian ini menggunakan metode eksperimental dengan parameter besar butir resin coated sand dan temperatur pemanasan. Dari hasil pengujian didapatkan nilai kekuatan tekan, geser, dan tarik tertinggi dihasilkan oleh pasir dengan ukuran besar butir kurang dari $300 \mu \mathrm{m}$. Temperatur pemanasan yang tinggi membuat ikatan antar pasir semakin kuat dan nilai kekuatan semakin tinggi.
\end{abstract}

\section{Keywords:}

resin coated sand;

grain size;

compressive strength;

shear strength;

tensile strength.

\section{Abstract}

Casting is a manufacturing process that uses molten metal and molds to obtain a product that is closer to its final geometry. The quality of casting products is influenced by several factors and one of the important factors is the mold. The sand that is often used in making molds is resin coated sand, since this sand will bond to one another if it is heated. The research focus is determine the effects of grain size and heating temperature of resin coated sand on the mechanical properties of the mold which include compressive, shear and tensile strength. This study used an experimental method with large parameters of resin coated sand and heating temperature. From the test results, the highest compressive, shear and tensile strength values are Produced by sand with grain size less than $300 \mu \mathrm{m}$ are identified.. The high heating temperature makes the bonds between the sands stronger and the strength value is higher.

\footnotetext{
*Penulis korespondensi: 


\section{Pendahuluan}

Perkembangan dan kemajuan teknologi dewasa ini berjalan dengan cepat khususnya pada industri pengolahan dan pembentukan logam. Salah satu indutri pengolahan dan pembentukan logam adalah industri pengecoran logam dimana industri ini mampu membuat produk dalam berbagai bentuk dengan cetakan sesuai dengan kebutuhan. Pengecoran merupakan suatu proses manufaktur yang menggunakan logam cair dan cetakan untuk memperoleh produk yang mendekati geometri akhirnya [1]. Dalam proses pengecoran, cetakan menjadi hal yang penting karena akan berpengaruh terhadap kualitas produk yang dihasilkan. Jenis cetakan yang digunakan dalam pengecoran secara umum terbagi menjadi dua yaitu cetakan sekali pakai dan cetakan permanen [2]. Salah satu cetakan sekali pakai yang umum digunakan adalah cetakan dengan menggunakan material pasir. Pada pembuatan cetakan pasir dapat menggunakan pasir alami yang telah dibersihkan atau pasir buatan yang ditambahkan zat-zat pengikat seperti bentonit, resin furan, air kaca, dan resin fenol yang bertujuan untuk memperkuat atau mempermudah dalam proses pembuatan cetakan [3].

Resin coated sand (RCS) merupakan salah satu material yang dapat digunakan dalam pembuatan cetakan sekali pakai berbahan dasar pasir. Komposisi RCS terdiri dari pasir silika atau zicron, resin phenol, resin resik atau novolac, dan alkohol atau air sebagai pengganti pelarut. Seluruh bahan tersebut dicampur dan dilakukan pengeringan dengan teknik pemanasan sehingga diperoleh butiran pasir yang diselubungi dengan resin [4]. Hasil SEM dari RCS tersaji dalam Gambar 1.

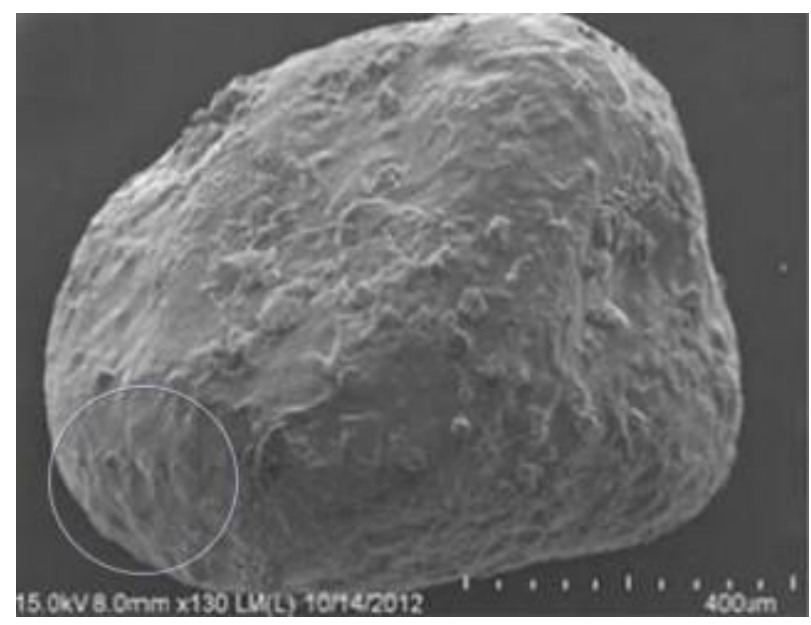

Gambar 1. SEM Image Of Resin Coated Sand [5]

Kualitas produk hasil pengecoran dipengaruhi oleh beberapa hal dan salah satu yang menjadi bagian penting dalam menentukan kualitas coran adalah cetakan. Pembuatan cetakan dengan menggunakan material RCS dilakukan dengan cara pemanasan agar terjadi ikatan antar butir pasir sehingga proses pemanasan yang tepat akan menghasilkan kualitas cetakan sesuai dengan kebutuhan. Faktor lain yang menentukan kualitas cetakan RCS adalah besar dari butiran pasir. Besar butir pasir mempengaruhi kekuatan, permebilitas cetakan, kekasaran permukaan cetakan, dan kualitas hasil coran logam yang dihasilkan diantaranya ialah terhadap terjadinya cacat dan kekasaran permukaan produk coran. Kualitas yang tinggi pada produk coran sangat dibutuhkan terutama untuk komponenkomponen produk manufaktur, otomotif, infrastruktur, dan transportasi.

Penelitian terkait pengaruh ukuran butir pasir dan jenis pengikat telah dilakukan dengan menggunakan pasir River Niger yang diikat dengan ukpor clay. Pasir dengan ukuran butir $355 \mu \mathrm{m}$ dan $500 \mu \mathrm{m}$ menghasilkan kekuatan tekan pasir basah sebesar $33,60 \mathrm{kN} / \mathrm{m}^{2}$ dan kekuatan tekan kering sebesar $322,00 \mathrm{kN} / \mathrm{m}^{2}$. Nilai permeabilitas berkurang dari 8,00 hingga 6,80 seiring menurunnya ukuran butir pasir dari $1000 \mu \mathrm{m}$ menjadi $125 \mu \mathrm{m}$, sedangkan mouldabilitynya menjadi semakin baik [6]. Penelitian mengenai pengaruh pengikat terhadap sifat cetakan pasir dilakukan pada campuran pasir dengan kandungan silika $89,9 \%$ serta lumpur yang mengandung $67,2 \%$ silika dan $24,5 \%$ alumina. Sedangkan pasir yang digunakan mempunyai grain fineness number (GFN) 40,01 dan ukuran butir rata-rata $421,70 \mu \mathrm{m}$. Hasil pengujian menunjukkan nilai kekuatan tekan basah pasir cetak adalah $35,70 \mathrm{kN} / \mathrm{m}^{2}$, kekuatan tekan kering 591,50 kN/m², kekuatan geser basah $21,00 \mathrm{kN} / \mathrm{m}^{2}$, kekuatan geser kering $77,00 \mathrm{kN} / \mathrm{m}^{2}$, dan mouldability 94,37\% [7]. Penelitian terhadap pengaruh perbandingan campuran partikel pasir dan temperatur penuangan terhadap hasil kekerasan, porositas, dan struktur mikro piston aluminium cor yang digunakan pada silinder brakemaster. Kombinasi campuran pasir kasar (+4750 $+300 \mu \mathrm{m})$ dan halus $(-300-75 \mu \mathrm{m})$ dengan perbandingan pasir kasar halus 80:20 menghasilkan morpologi permukaaan, sifat kekerasan, dan porositas yang terbaik. Kekerasan coran aluminium yang dicapai sekitar 60 BHN dan cacat porositas yang terjadi hanya sekitar $1 \%$ dimana penuangan dilakukan pada temperatur $750 \pm 10^{\circ} \mathrm{C}$ [8].

Pembuatan peralatan atau komponen dalam bidang infrastruktur, trasportasi, dan pertahanan nasional banyak membutuhkan proses pengecoran. Kualitas produk tersebut sangat tergantung pada proses pengecoran yang dilakukan. Faktor utama yang harus diperhatikan untuk menghasilkan kualitas produk coran yang baik adalah tersedianya cetakan yang sesuai. Berdasarkan latar belakang dan penelitian yang telah dilakukan dimana faktor yeng berpengaruh terdahap cetakan adalah jenis pengikat dan pasir yang digunakan. Besar butir pasir dan temperatur pemanasan cetakan juga faktor lain yang berpengaruh terhadap kualitas cetakan dan produk coran.

Tujuan dari penelitian yaitu untuk mengetahui pengaruh besar butir RCS dan temperatur pemanasan cetakan terhadap sifat mekanis cetakan yang meliputi kekuatan tekan, kekuatan tarik, dan kekuatan geser. Diharapkan dengan mengetahui sifat mekanis yang sesuai, maka cacat pada produk coran dapat diminimalkan sehingga efisiensi produksi meningkat.

\section{Metode}

Metode penelitian yang digunakan dalam penelitian ini adalah metode eksperimental. Tahapan proses penelitian ini digambarkan dalam diagram alir yang ditunjukkan oleh Gambar 2. 


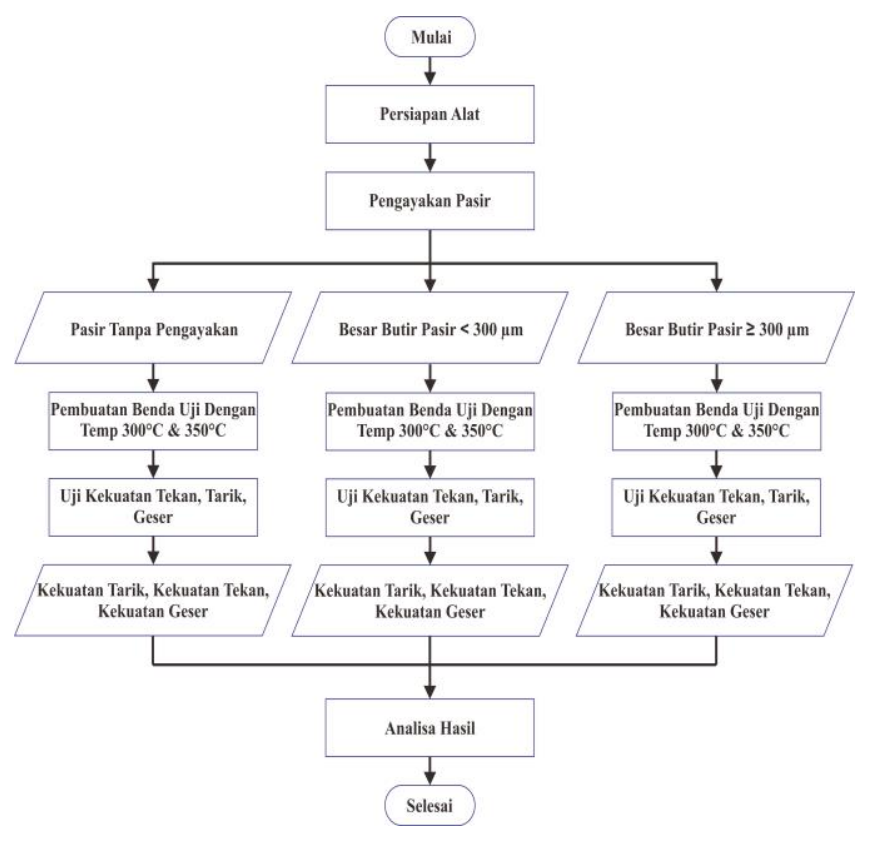

Gambar 2. Diagram Alir Penelitian

Tabel 1. Parameter Penelitian

\begin{tabular}{lc}
\hline \multicolumn{1}{c}{ Besar Butir RCS } & $\begin{array}{c}\text { Tanpa pengayakan } \\
\text { Besar butir }<\mathbf{3 0 0} \boldsymbol{\mu m} \\
\text { Besar butir } \geq \mathbf{3 0 0} \boldsymbol{\mu \mathbf { m }}\end{array}$ \\
\hline Temperatur Pemanasan & $300^{\circ} \mathrm{C}$ \\
Waktu Pemanasan & $350^{\circ} \mathrm{C}$ \\
Cetakan & 12 menit \\
\hline
\end{tabular}

\subsection{Alat dan Bahan}

Bahan yang digunakan pada penelitian ini adalah resin coated sand (RCS) dan peralatan yang digunakan pada penelitian adalah timbangan, cawan, cetakan specimen, oven, sand reamer, universal strength machine, universal sand strength machine, mesin pengguncang. Pada penelitian ini, variasi parameter yang digunakan dapat dilihat pada Tabel 1 .

\subsection{Pembuatan Spesimen}

Langkah yang dilakukan sebelum pengujian pasir cetak adalah pembuatan spesimen uji. Pada penelitian ini pembuatan spesimen uji dilakukan dengan pemadatan RCS menggunakan sand rammer yang ditunjukan oleh Gambar 3. Dalam pengujian pasir cetak menggunakan ukuran spesimen 2 in $\times 2$ in menurut AFS atau setara DIN $50 \mathrm{~mm}$ $\times 50 \mathrm{~mm}$, dan ukuran spesimen 1 in $\times 1$ in menurut AFS atau setara DIN $22.4 \mathrm{~mm} \times 22.4 \mathrm{~mm}$ [9]. Adapun arah gaya yang bekerja terlihat pada Gambar 4. Jumlah spesimen yang dilakukan pengujian berjumlah tiga buah untuk masing-masing parameter.

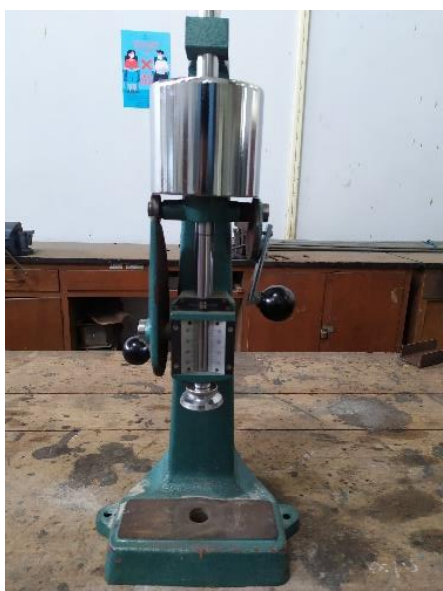

Gambar 3. Sand Reamer
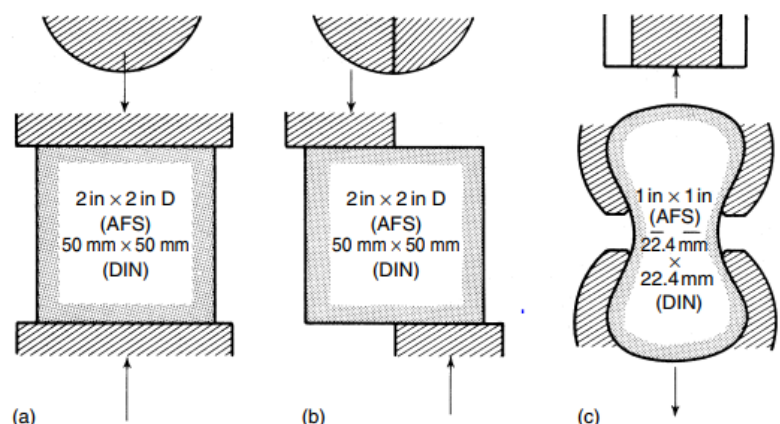

Gambar 4. (a) Gaya Tekan (b) Gaya Geser (c) Gaya Tarik [9]

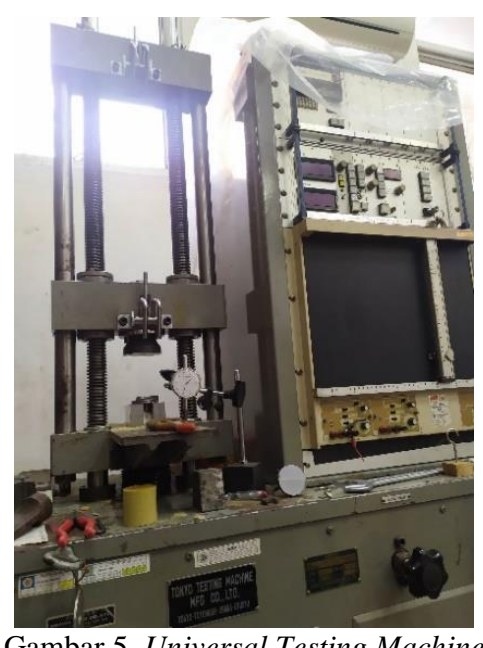

Gambar 5. Universal Testing Machine

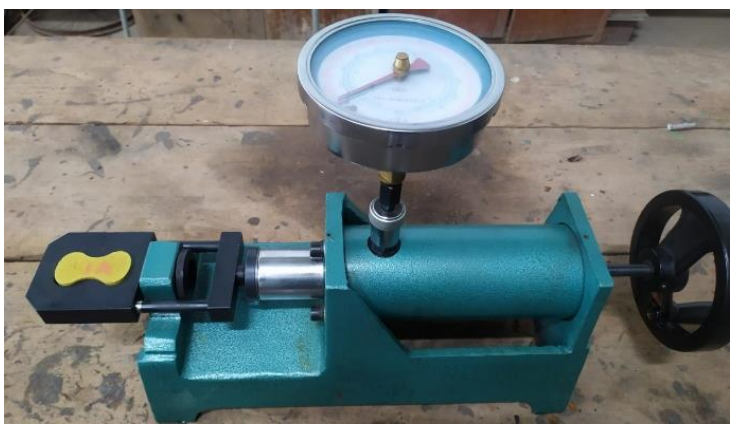

Gambar 6. Universal Sand Strength Machine 


\subsection{Pengujian}

Pengujian kekuatan sifat mekanis merupakan pengujian untuk mengetahui kemampuan mekanis dari material pasir cetak. Pengujian sifat mekanis dibedakan menjadi tiga yaitu: kekuatan tekan, kekuatan geser, dan kekuatan tarik [10]. Pengujian kekuatan pasir cetak mengunakan universal testing machine untuk pengujian kekuatan tekan dan kekuatan geser seperti ditunjukan oleh Gambar 5. Sedangkan untuk pengujian kekuatan tarik dilakukan dengan menggunakan universal sand strength machine yang tersaji pada Gambar 6 .

\section{Hasil dan Pembahasan}

Pada penelitian ini ditunjukan hasil pengujian dari pengunaan resin coated sand (RCS) terhadap variasi besar butir yang dapat digunakan dalam pembuatan cetakan. Pembuatan spesimen dilakukan pada variasi temperatur $300^{\circ} \mathrm{C}$ dan $350^{\circ} \mathrm{C}$ dengan waktu pemanasan 12 menit. Hasil dari pengujian kekuatan tekan terhadap variasi butir RCS dan temperatur mengunakan universal testing machine didapatkan nilai kekuatan tekan seperti tertera pada Tabel 2.

Tabel 2. Hasil Pengujian Kekuatan Tekan

\begin{tabular}{ccc}
\hline & \multicolumn{2}{c}{ Kekuatan Tekan $\left(\mathbf{N} / \mathbf{c m}^{2}\right)$} \\
& Temp 300 $^{\circ} \mathbf{C}$ & Temp 350 $^{\circ} \mathbf{C}$ \\
\hline Tanpa & 244,586 & 540,127 \\
Pengayakan & 247,745 & 784,713 \\
& 269,554 & 835,669 \\
\hline \multirow{2}{*}{ Besar Butir } & 362,803 & 927,389 \\
$<\mathbf{3 0 0} \boldsymbol{\mu m}$ & 359,236 & 917,197 \\
& 358,115 & 840,764 \\
\hline \multirow{2}{*}{ Besar Butir } & 63,694 & 280,225 \\
$\geq \mathbf{3 0 0} \boldsymbol{\mu m}$ & 58,701 & 310,828 \\
& 55,236 & 305,732 \\
\hline
\end{tabular}

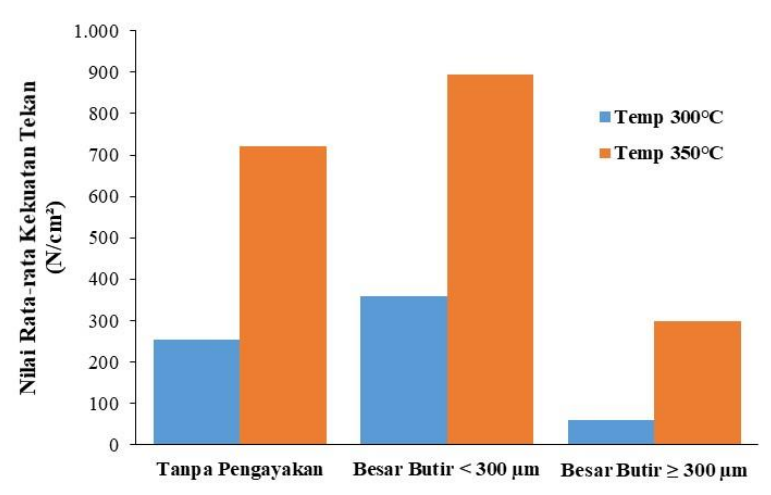

Gambar 7. Grafik Nilai Rata-rata Kekuatan Tekan

Hasil pengujian kekuatan tekan dengan variasi besar butir dan temperatur diperoleh variasi nilai kekuatan. Kekuatan tekan pada termperatur pemanasan $300^{\circ} \mathrm{C}$ berada pada nilai $55,236-362,803 \mathrm{~N} / \mathrm{cm}^{2}$ dengan nilai kekuatan tekan tertinggi diperoleh pada spesimen dengan besar butir RCS $<300 \mu \mathrm{m}$ dan nilai kekuatan tekan terendah pada spesimen dengan besar butir RCS $\geq 300 \mu \mathrm{m}$. Pada pemanasan spesimen dengan temperatur $350^{\circ} \mathrm{C}$ diperoleh nilai kekuatan tekan lebih tinggi dibandingkan pada pemanasan dengan temperatur $300^{\circ} \mathrm{C}$. Nilai kekuatan tekan tertinggi pada temperatur pemanasan $350^{\circ} \mathrm{C}$ yaitu 927,389 $\mathrm{N} / \mathrm{cm}^{2}$ dengan besar butir $<300 \mu \mathrm{m}$.

Distribusi besar butir RCS dan temperatur pemanasan memiliki pengaruh terhadap kekuatan tekan. Nilai kekuatan tekan rata-rata dengan temperatur pemanasan $300^{\circ} \mathrm{C}$ yaitu $253,962 \mathrm{~N} / \mathrm{cm}^{2}$ untuk pasir tanpa pangayakan, 360,052 $\mathrm{N} / \mathrm{cm}^{2}$ untuk pasir dengan besar butir $<300 \mu \mathrm{m}$, dan 59,210 $\mathrm{N} / \mathrm{cm}^{2}$ untuk pasir dengan besar butir $\geq 300 \mu \mathrm{m}$. Sedangkan nilai kekuatan tekan rata-rata dengan temperatur pemanasan $350^{\circ} \mathrm{C}$ yaitu $720,170 \mathrm{~N} / \mathrm{cm}^{2}$ untuk pasir tanpa pangayakan, $895,117 \mathrm{~N} / \mathrm{cm}^{2}$ untuk pasir dengan besar butir < 300 $\mu \mathrm{m}$, dan 298,938 N/cm² untuk pasir dengan besar butir $\geq 300$ $\mu \mathrm{m}$. Perbandingan nilai rata-rata kekuatan tekan dengan besar butir dan temperatur pemanasan lebih lengkap tersaji pada Gambar 7.

Berdasarkan dari Gambar 7 terlihat bahwa pasir RCS dengan besar butir $<300 \mu \mathrm{m}$ memiliki nilai kekuatan tekan tertinggi, hal ini terjadi karena pada ukuran $<300 \mu \mathrm{m}$ memiliki ukuran butir yang kecil sehingga ikatan antar butir pasir memiliki kerapatan dan kepadatan yang tinggi. Sedangkan untuk pasir RCS tanpa pengayaan terdiri distribusi besar butir gabungan dari variasi $<300$ dan $\geq 300$ $\mu \mathrm{m}$ memiliki nilai kekuatan tekan lebih rendah dibandingkan dengan besar butir pasir $<300 \mu \mathrm{m}$. Besar butir pasir $\geq 300 \mu \mathrm{m}$ memiliki nilai kekuatan tekan yang paling rendah dimana distribusi besar butir didominasi pasir kasar karena daya ikat antar butir pasir yang rendah sehingga kerapatan dan kepadatan cetakan rendah. Temperatur pemanasan juga mempengaruhi nilai kekuatan tekan yang dihasilkan. Pada temperatur $350^{\circ} \mathrm{C}$ nilai kekuatan tekan lebih tinggi dibandingkan temperatur $300^{\circ} \mathrm{C}$. Hal ini sejalan dengan hasil penelitian yang menyatakan bahwa nilai kekuatan tekan dipengaruhi oleh ukuran butir dan kadar pengikat [11].

Pengujian terhadap kekuatan geser diperoleh nilai kekuatan geser yang berbeda yang dipengaruhi oleh besar butir dan temperatur pemanasan. Perbedaaan nilai kekuatan geser terlihat sangat signifikan untuk besar butir $\geq 300 \mu \mathrm{m}$ jika dibandingkan dengan pasir tanpa pengayakan dan pasir dengan besar butir $<300 \mu \mathrm{m}$ untuk seluruh variasi temperatur pemanasan. Hasil pengujian kekuatan geser pada pasir dengan besar butir $\geq 300 \mu \mathrm{m}$ sebesar yaitu $12,229-20,790 \mu \mathrm{m}$ untuk temperatur $300^{\circ} \mathrm{C}$ dan $20,382-$ $86,624 \mu \mathrm{m}$ untuk temperatur $350^{\circ} \mathrm{C}$. Hasil pengujian kekuatan geser selengkapnya dapat dilihat pada Tabel 3.

Tabel 3. Hasil Pengujian Kekuatan Geser

\begin{tabular}{ccc}
\hline & \multicolumn{2}{c}{ Kekuatan Geser $\left(\mathbf{N} / \mathbf{c m}^{2}\right)$} \\
& Temp 300 $^{\circ} \mathbf{C}$ & Temp 350 $^{\circ} \mathbf{C}$ \\
\hline Tanpa & 70,420 & 188,535 \\
Pengayakan & 73,783 & 275,159 \\
& 100,994 & 285,350 \\
\hline \multirow{2}{*}{ Besar Butir } & 90,701 & 275,159 \\
$<\mathbf{3 0 0} \boldsymbol{\mu m}$ & 97,019 & 285,350 \\
& 85,503 & 264,968 \\
\hline \multirow{2}{*}{ Besar Butir } & 14,166 & 86,624 \\
$\geq \mathbf{3 0 0} \boldsymbol{\mu m}$ & 12,229 & 20,382 \\
& 20,790 & 35,669 \\
\hline
\end{tabular}


Nilai kekuatan geser rata-rata dengan temperatur pemanasan $300^{\circ} \mathrm{C}$ adalah $81,732 \mathrm{~N} / \mathrm{cm}^{2}$ untuk pasir tanpa pengayakan, $91,074 \mathrm{~N} / \mathrm{cm}^{2}$ untuk pasir dengan besar butir < 300 , dan $15,728 \mathrm{~N} / \mathrm{cm}^{2}$ untuk pasir dengan besar butir $\geq$ $300 \mu \mathrm{m}$. Sedangkan nilai kekuatan geser rata-rata dengan temperatur pemanasan $350^{\circ} \mathrm{C}$ yaitu $249,682 \mathrm{~N} / \mathrm{cm}^{2}$ untuk pasir tanpa pangayakan, $275,159 \mathrm{~N} / \mathrm{cm}^{2}$ untuk pasir dengan

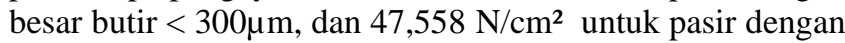
besar butir $\geq 300 \mu \mathrm{m}$. Perbandingan nilai rata-rata kekuatan geser dengan besar butir dan temperatur pemanasan lebih lengkap dapat dilihat pada Gambar 8 .

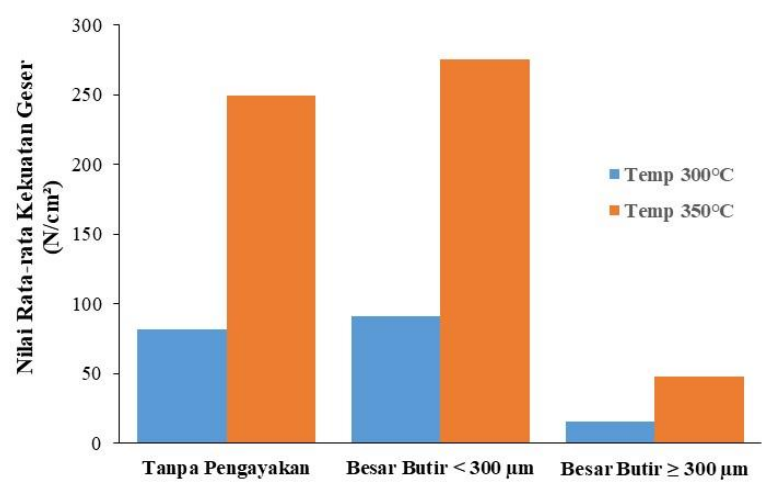

Gambar 8. Grafik Nilai Rata-rata Kekuatan Geser

Tabel 4. Hasil Pengujian Kekuatan Tarik

\begin{tabular}{ccc}
\hline & \multicolumn{2}{c}{ Kekuatan } \\
& Temp 300 $^{\circ} \mathbf{C}$ & Temp 350 $^{\circ} \mathbf{C}$ \\
\hline \multirow{2}{*}{ Tanpa } & 220 & 320 \\
Pengayakan & 220 & 330 \\
& 280 & 310 \\
\hline \multirow{2}{*}{ Besar Butir } & 250 & 320 \\
$<\mathbf{3 0 0} \boldsymbol{\mu m}$ & 460 & 350 \\
& 390 & 360 \\
\hline \multirow{2}{*}{ Besar Butir } & 100 & 120 \\
$\geq \mathbf{3 0 0} \boldsymbol{\mu m}$ & 150 & 130 \\
& 180 & 140 \\
\hline
\end{tabular}

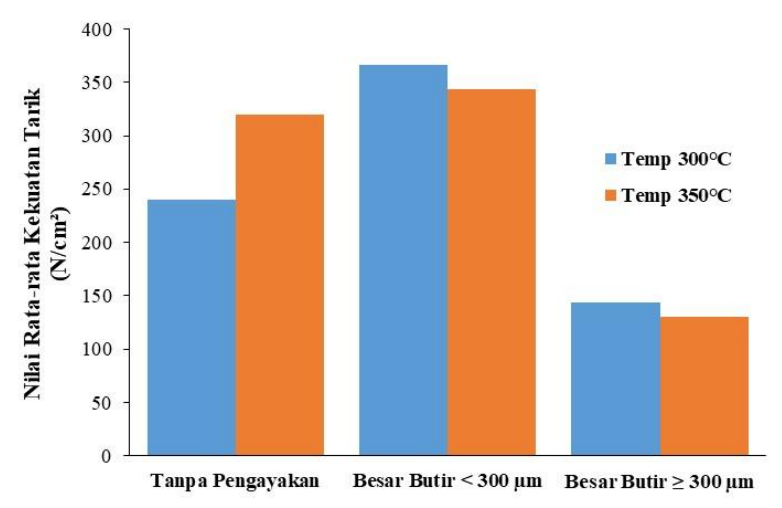

Gambar 9. Grafik Nilai Rata-rata Kekuatan Tarik
Distribusi besar butir RCS mempengaruhi nilai kekuatan geser rata-rata yang dihasilkan, dimana terdapat perbedaan nilai kekuatan geser antara ketiga variasi tersebut. Besar butir yang digunakan mempengaruhi kerapatan dan kepadatan terhadap cetakan RCS, dimana semakin kecil besar butir didapatan nilai kekuatan geser yang tinggi. Hal ini dibuktikan dengan nilai kekuatan geser dengan hasil variasi $<300 \mu \mathrm{m}$ memiliki nilai kekuatan geser tertinggi dan besar butir dengan ukuran $\geq 300 \mu \mathrm{m}$ memiliki nilai kekuatan geser yang paling rendah dimana distribusi besar butir didominasi jenis pasir kasar. Nilai kekuatan yang tinggi diperlukan selama penuangan logam untuk mengurangi keruntuhan cetakan, retak, erosi, dan untuk meningkatkan kualitas pengecoran [12].

Pada pengujian kekuatan tarik didapatkan variasi nilai kekuatan tarik seperti tersaji dalam Tabel 4. Kekuatan tarik pada temperatur pemanasan $300^{\circ} \mathrm{C}$ berada pada nilai 100 $460 \mathrm{~N} / \mathrm{cm}^{2}$ dengan nilai kekuatan tarik tertinggi diperoleh pada spesimen dengan besar butir RCS $<300 \mu \mathrm{m}$ dan nilai kekuatan tarik terendah pada spesimen dengan besar butir RCS $\geq 300 \mu \mathrm{m}$. Pada pemanasan spesimen dengan temperatur $350^{\circ} \mathrm{C}$ diperoleh nilai kekuatan tarik antara $120-360 \mathrm{~N} / \mathrm{cm}^{2}$ dengan nilai kekuatan tarik maksimal lebih rendah dibanding pada pemanasan dengan temperatur $300^{\circ} \mathrm{C}$. Nilai kekuatan tarik rata-rata dengan temperatur pemanasan $300^{\circ} \mathrm{C}$ adalah $240 \mathrm{~N} / \mathrm{cm}^{2}$ untuk pasir tanpa pengayakan, $366,667 \mathrm{~N} / \mathrm{cm}^{2}$ untuk pasir dengan besar butir $<300$, dan $143,333 \mathrm{~N} / \mathrm{cm}^{2}$ untuk pasir dengan besar butir $\geq$ $300 \mu \mathrm{m}$. Sedangkan nilai kekuatan tarik rata-rata dengan temperatur pemanasan $350^{\circ} \mathrm{C}$ yaitu $320 \mathrm{~N} / \mathrm{cm}^{2}$ untuk pasir tanpa pangayakan, $343,333 \mathrm{~N} / \mathrm{cm}^{2}$ untuk pasir dengan besar butir $<300 \mu \mathrm{m}, 130 \mathrm{~N} / \mathrm{cm}^{2}$ untuk pasir dengan besar butir $\geq 300 \mu \mathrm{m}$. Hubungan besar butir, temperatur pemanasan, dan kekuatan tarik rata-rata tersaji pada Gambar 9.

Dari grafik pada Gambar 9 terlihat bahwa kekuatan tarik rata-rata tertinggi dicapai pada kondisi besar butir < $300 \mu \mathrm{m}$ dengan temperatur pemanasan $300^{\circ} \mathrm{C}$. Hal tesebut juga terjadi untuk pasir dengan besar butir $\geq 300 \mu \mathrm{m}$, dimana kekuatan tarik rata-rata yang diperoleh untuk temperatur pemanasan $350^{\circ} \mathrm{C}$ sedikit lebih rendah dibandingkan temperatur pemanasan $300^{\circ} \mathrm{C}$. Namun jika ditinjau dari ukuran besar butir, hasil pengujian tarik memperoleh nilai maksimal pada pasir yang paling halus atau pasir dengan ukuran besar butir $<300 \mu \mathrm{m}$. Hal tersebut terjadi karena pasir dengan besar butir yang kecil atau halus memiliki luas bidang kontak antar butir pasir yang semakin besar sehingga kekuatan tarik yang dihasilkan akan semakin besar [13].

Jika melihat dari hasil pengujian yang telah dilakukan, besar butir pasir RCS berpengaruh terhadap nilai kekuatan yang dihasilkan. Pasir dengan besar butir $<300 \mu \mathrm{m}$ memiliki nilai kekuatan yang tertinggi. Selain besar butir, temperatur pemanasan juga berpengaruh terhadap nilai kekuatan yang dihasilkan. Pengujian dengan temperatur pemanasan $350^{\circ} \mathrm{C}$ menghasilkan nilai kekuatan yang jauh lebih tinggi dibandingkan temperatur pemanasan $300^{\circ} \mathrm{C}$, meskipun pada uji tarik sedikit terdapat perbedaan tetapi jaraknya tidak terlalu jauh. Temperatur juga berpengaruh terhadap nilai kekuatan yang dihasilkan karena pada 
temperatur $350^{\circ} \mathrm{C}$ bahan pengikat telah mengikat pasir lebih baik dibandingkan temperatur $300^{\circ} \mathrm{C}$ sehingga ikatan antar pasir semakin kuat dan nilai kekuatan semakin tinggi [14]. Faktor lain yang dapat mempengaruhi sifat mekanis cetakan adalah kadar bahan pengikat dan bahan dasar pasir yang digunakan. Penggunaan pasir $100 \%$ daur ulang akan menghasilkan nilai kekuatan yang lebih rendah jika dibandingkan menggunakan pasir 50\% daur ulang [15].

\section{Kesimpulan}

Dari hasil penelitian, pengujian, dan analisis yang telah dilakukan maka dapat disimpulkan bahwa ukuran besar butir RCS dan temperatur pemanasan spesimen berpengaruh terhadap sifat mekanis dihasilkan. Pasir dengan ukuran besar butir $<300 \mu \mathrm{m}$ memiliki nilai kekuatan semua pengujian sifat mekanis. Sedangkan pemanasan spesimen dengan temperatur $350^{\circ} \mathrm{C}$ menghasilkan nilai kekuatan yang lebih baik dibandingkan pada temperatur $300^{\circ} \mathrm{C}$.

\section{Daftar Pustaka}

[1] R. A. Ardiansyah, Sukarni dan R. P. Puspitasari, "Pengaruh Penggunaan Serbuk Dry Cell Sebagai Pengikat Terak Pada Pengecoran Logam Terhadap Kualitas Coran," Jurnal Teknik Mesin, vol. 2, pp. 1-9, 2016.

[2] V. Boljanovic, Metal Shaping Processes: Casting and Molding; Particulate Processing; Deformation Processes; and Metal Removal, Indutrial Press INC, 2009.

[3] I. M. Astika, D. P. Negara dan M. A. Susantika, "Pengaruh Jenis Pasir Cetak dengan Zat Pengikat Bentonit Terhadap Sifat Permeabilitas dan Kekuatan Tekan Basah Cetakan Pasir (Sand Casting)," Jurnal Ilmiah Teknik Mesin Cakram, vol. 4, pp. 132-138, 2010.

[4] Y. Lu, H. Wang dan A. A. Luo, "Process Simulation and Experimental Validation of Resin-Bonded Silica Sand Mold Casting," AFS Transactions, vol. 125, pp. 215-220, 2017.

[5] R. Ma, X. Han, F. Bao, J. Gao, S. Jiang, X. Zhang, K. Chen dan C. Yan, "Preparation and Characterization of Polymeric Ultra-Low-Density Proppants: Epoxy/Phenolic Resin-Coated Polystyrene/Graphite Microspheres," J. Polym. Mater, vol.

[15] E. Widianto, A. Santosa, Kardiman dan V. Nabunome, "Sintesis dan Karakterisasi Sifat Mekanik Cetakan Pasir Pengecoran Logam Berbasis Pasir Recycle dengan Penambahan Resin," Lontar Jurnal Teknik Mesin Undana, vol. 4, pp. 9-12, 2017.
33, pp. 259-270, 2016.

[6] F. O. Edoziuno, R. O. Akaluzia, B. U. Odoni dan C. C. Nwaeju, "Effect of Base Sand Particle Size on The Properties of Synthetic Moulding Sand," International Journal of Research in Engineering and Innovation, vol. 1, no. 3, pp. 225-229, 2017.

[7] F. O. Edoziuno, A. O. Oyibo dan C. C. Nwaeju, "Preparation of Synthetic Moulding Sand Using Local Raw Materials," International Journal of Advanced Engineering and Technology, vol. 1, no. 1, pp. 28-31, 2017.

[8] O. O. Ajibola, D. T. Oloruntoba dan B. O. Adewuyi, "Effects of Moulding Sand Permeability and Pouring Temperatures on Properties of Cast 6061 Aluminium Alloy," International Journal of Metals, pp. 1-13, 2015.

[9] P. Beeley, Foundry Technology, Butterworth-Heinemann, 2001.

[10] N. R. A. D. Putra, P. Murdanto dan Wahono, “Analisis Sifat Mekanik dan Permeabilitas Pasir Cetak Menggunakan Bahan Campuran Kaolin Pada Sand Casting," Jurnal Teknik Mesin dan Pembelajaran, vol. 1, pp. 1-6, 2018.

[11] M. A. Haryanto, N. A. Mufarida dan Kosjoko, "Analisis Pengaruh Variasi Ukuran Butir dan Kadar Pengikat Terhadap Kekuatan Tekan Cetakan Pasir," Jurnal Fakultas Teknik Universitas Muhammadiyah Jember, pp. 1-7, 2015.

[12] P. A. Ihom, J. Agunsoye, E. . E. Anbua dan . J. Ogbodo, "Effects of Moisture Content on the Foundry Properties of Yola Natural Sand," Leonardo Electronic Journal of Practices and Technologies, no. 19, pp. 85-96, 2011.

[13] S. Devianty, A. Syuhri dan H. Arbiantara, "Analisis Kekuatan Tarik dan Tekan Cetakan Pasir akibat Variasi Ukuran Butir dan Kadar Pengikat Pasir Cetak," Jurnal Rotor, vol. 7, 2014.

[14] R. Kusnowo, S. Gunara dan S. G. Fauzan, "Pengaruh Waktu dan Temperatur Pemanasan Resin Coated Sand terhadap Sifat Mekanik dan Kualitas Produk Cor pada Metode Shell Molding," Jurnal Energi dan Teknologi Manufaktur, vol. 2, pp. 7-12, 2019. 